\title{
Kompilasi Hukum Islam dan Rancangan Undang-Undang RI tentang Hukum Terapan Peradilan Agama
}

\section{(Studi Evaluatif Terhadap Materi dan Dasar Hukum Pemberlakuannya)}

\author{
Amir Mu'allim
}

It is clearly proved that the Compilation of Islamic law which was issued by the Presidential Decree no.1/1991 is not far from weaknesses. The weaknesses appear in some chapters and articles, such as in the articles on marriage. Indeed, the content also shows contradiction with other regulations. Therefore, the effort to issue the Regulation on the Implementation of Islamic Law (Udang-Undang Terapan) must be strongly supported due to the need for creating better implementation of Islamic legal system in Indonesia.

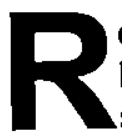
eformulasi dan reposisi Hukum Is lam di Indonesia pada masa sekarang ini sudah saatnya harus menjadi perhatian yang serius. Sudah lebih 50 tahun sejak Indonesia merdeka keberadaan Hukum Islam masih terkesan dimarjinalkan, artinya tidak begitu banyak mendapat perhatian. Hal ini nampak apabila disejajarkan dengan Hukum Positif maka Hukum Islam dalam kompetisinya selalu dalam posisi yang kaiah atau tertinggal. Dalam hitungan jari Hukum Islam yang dituangkan dalam bentuk formal masih sangat minim. Demikian pula Hukum Islam yang dituangkan dalam bentuk materiil.

Salah satu dari sejumlah Hukum Islam yang dituangkan dalam bentuk materiil adalah Kompilasi Hukum Islam (KHI) yang dalam perjalanannya sudah mencapai usia hampir 13 tahun, namun keberadaannya masih ada permasalahan. Permasalahan yang pertama adalah sejauhmana materi KHI dapat menjawab dan menyelesaikan masalah-masalah yang berkaitan dengan Hukum Islam sesuai dengan tuntutan dan perkembangan masyarakat, karena ada kritik yang sering dilontarkan terhadap materi $\mathrm{KHI}$ adalah bahwa materi $\mathrm{KHI}$ masih bemuansa "Taklid" secara ekstrim terhadap kitab-kitab figh mazhab. Di sisi lain persoalan yang sangat mendasar adalah dasar pemberlakuan $\mathrm{KHI}$ masih lemah yaitu INPRES (Instruksi Presiden No. 1 tahun 1991).

Dari dua persoalan mendasar tersebut maka penting untuk dievaluasi tentang materi dan dasar tentang pemberlakuan $\mathrm{KHI}$ di Indonesia. Hal ini pemerintah sudah merancang penerapan undang-undang tentang Hukum Terapan Peradilan Agama maka dalam beberapa hal yang ada dalam KHI perlu dikonfirmasikan. 
Studi Evaluatif terhadap Materi Kompilasi Hukum Islam dan Rancangan UU RI tentang Hukum Terapan Peradilan Agama.

Kelahiran Kompilasi Hukum Islam (KHI) sebagai bagian pelaksanaan syariat Islam di Indonesia menimbulkan kecurigaan sebagian pihak dalam masyarakat terhadap kemungkinan bangkitnya semangat piagam Jakarta. ${ }^{1}$ Kecurigaan ini muncul karena keberadaan $\mathrm{KHI}$ mendapat dukungan pemerintah yang ditandai dengan adanya Inpres RI no. 1 tahun 1991 tentang Pemasyarakatan Kompilasi Hukum Islam. Padahal munculnya KHI didasarkan pada keinginan menerapkan aturan-aturan hukum kekeluargaan yang pada waktu itu penerapannya masih mengacu pada berbagai referensi kitab-kitab fiqh dan belum ada acuan lain.

Dilacak dari proses kelahirannya ide pembuatan $\mathrm{KHI}$ melibatkan berbagai pihak baik dari kalangan akademisi, praktisi maupun para ulama dan didukung dengan berbagai sumber rujukan. Kini perjalanan KHI sudah mencapai masa 13 (tiga belas) tahun dan sudah diujikan di masyarakat tentang pelaksanaannya. Di sisi lain pemerintah sudah mengkritisinya sehingga muncul rancangan Undang-Undang Republik Indonesia tentang Hukum Terapan Peradilan Agama yang merupakan pengembangan dari Kompilasi Hukum Islam.

Terlepas dari penilaian masyarakat maupun upaya pemerintah dalam pemberlakuan $\mathrm{KHI}$, penulis merasa perlu memberikan sedikit evaluasi tentang materi $\mathrm{KHI}$ sekaligus mengkomparasikan dengan rancangan pemerintah tentang Hukum Terapan Peradilan Agama. Beberapa hal mengenai evaluasi $\mathrm{KHI}$ sudah dikomentari oleh Dadan Muttaqien ${ }^{2}$ yang penekanannya lebih banyak pada persoalan kewarisan dan wasiat. Agar tidak duplikasi maka penulis lebih menekankan pada materi perkawinan. Sudah barang tentu evaluasi ini tidak bermaksud menggurui pada beliau-beliau yang terlibat dalam penyusunan Kompilasi Hukum Islam akan tetapi sekedar wacana yang mungkin dapat menjadi bahan pertimbangan selanjutnya.

$\mathrm{Di}$ antara materi $\mathrm{KHI}$ yang perlu dievaluasi dan mendapat perhatian adalah:

\section{Pasal 4 Bab /I}

Bunyi teks pasal tersebut adalah: Perkawinan adalah sah, apabila dilakukan menurut Hukum Islam sesuai dengan pasal 2 ayat (1) Undang-Undang No. 1 Tahun 1974 tentang perkawinan.

Perlu diketahui bahwa Inpres no. 1/1991 diperuntukkan khususnya bagi orang Islam yang dalam persoalan seperti perkawinan mempunyai dasar hukum dan kepercayaan yang berbeda dengan agama lain. Berkaitan dengan ini maka lebih meyakinkan apabila bunyi teks pasal 4 tersebut hanya sampai kata-kata "Hukum Islam". Tambahan kalimat "sesuai dengan pasal 2 ayat (1) Undangundang no. 1 tahun 1974 tentang perkawinan" memberikan kesan mementahkan makna hukum islam itu sendiri, karena pasal 2 ayat (1) UU no. 1/ 1974 tersebut mengabsahkan seluruh proses perkawinan yang dilaksanakan oleh

1 Sudirman Tebba, 2003, Sosiologi Hukum Islam, cet.1 (Yogyakarta: UII Press), hal.7

${ }^{2}$ Lihat Dadan Muttaqien, Beberapa istilah dan Pengertian dalam Kompilasi Hukum Islam yang perlu direvisi dalam buku Dadan Muttaqien, Sidik Tono dan Amir Mu'allim (Editor), 1999. Peradilan Agama \& Kompilasi Hukum Islam dalam Tata Hukum Indonesia (Yogyakarta: UII Press) hlm.182-186. 
agama-agama yang berlaku di Indonesia. Apabila dilacak dari aspek prosedur perkawinan yang dilaksanakan agama lain (selain Islam) terutama yang menyangkut prinsip dasar tentang syarat-syarat perkawinan dalam hal yang prinsip sangat berbeda sekali. Dalam pasal 6 sampai dengan pasal 12 UU No. 1 tahun 1974 tidak menyebutkan satupun syarat-syarat yang ada dalam Kompilasi Hukum Islam. Demikian pula rancangan Undang-Undang Republik Indonesia tentang Hukum Terapan Peradilan Agama yang merupakan penyempurnaan dari $\mathrm{KHI}$ bunyi teks tentang sahnya perkawinan masih sama dengan bunyi teks yang ada dalam $\mathrm{KHI}$, hanya berbeda daiam peletakan pasal. ${ }^{3}$

Prinsip tidak mencampur adukkan antara apa yang diyakini sebagai sesuatu yang hak dengan yang batil sesuai firman Allah yang artinya "Dan janganlah kamu campur adukkan yang hak dengan yang batil dan jangan kamu sembunyikan yang hak itu sedang kamu mengetahui" . ${ }^{4}$ Dikuatkan juga dengan kaidah fiqhiyah, bahwa apayang sudah diyakini tidak hilang dengan keraguraguan. $^{5}$

\section{Pasal 6}

Baik ayat (1) dan (2) pasal 6 memberi peluang interpretasi. Dalam ayat (1) dengan istilah "Setiap perkawinan harus dilangsungkan dihadapan dan dibawah pengawasan Pegawai Pencatat Nikah". Seolah-olah ada unsur tambahan dalam rukun karena kata "harus" dalam pengertian Hukum Islam berarti wajib. Demikian pula dalam ayat (2) tentang istilah "tidak mempunyai kekuatan hukum" dapat dipertanyakan hukum yang mana?, sebab kalau perkawinan itu sudah dilaksanakan menurut Hukum Islam dan memenuhi syarat dan rukun, maka sudah mempunyai kekuatan hukum dalam pandangan Hukum
Islam, kecuali yang dimaksudkan adalah tidak mempunyai kekuatan hukum positif.

Dalam rancangan Undang-undang Republik Indonesia tentang Hukum Terapan Peradilan Agama isi pasal $6 \mathrm{KHI}$ masih tetap, artinya baik isi dan redaksinya masih belum ada perubahan.

\section{Pasal 7}

Mengenai pasal 7 khususnya ayat (1) memberi kesan seolah-olah alat bukti itu hanya bukti tertulis atau surat-surat, karena dengan kalimat "Perkawinan hanya dapat dibuktikan dengan akte nikah..." mengandung pengertian satu-satunya. Padahal jenis alat bukti itu di samping alat bukti tertulis atau surat-surat juga alat bukti berupa saksi, persangkaan, pengakuan, sumpah, pemeriksaan setempat (Discente) dan keterangan ahli (expertise). ${ }^{6}$

Isi pasal 7 ayat (1) $\mathrm{KHI}$ ternyata masih sama dengan isi pasal 6 ayat (1) Rancangan Undang-Undang Republik Indonesia tentang Hukum Terapan Peradilan Agama, hanya beda peletakan pasal.

\section{Pasal 14}

Dalam Bab IV tertulis "Rukun dan Syarat Perkawinan". Selanjutnya pada bagian kesatu tertulis "Rukun" yang dilanjutkan dengan pasal 14. Anehnya

${ }^{3}$ Dalam rancangan UU RI tentang Hukum Terapan Peradilan Agama pasal tentang sahnya perkawinan dicantumkan dalam pasal 4.

${ }^{4}$ Q.S. Al Baqoroh (2): 42

5 lihat jalaludin As Suyuthi tth, Al Asybah wan Nadzair fil Furu (Beirut:Darul Fikri), hal.77

${ }^{6}$ Keterangan lebih luas tentang alat bukti, baca Roihan A Rasyid, 1991, Hukum Acara Peradilan Agama, cet.2 (Jakarta:Rajawali Pers), hal. 148-195. 
setelah mengemukakan rukun, pada bagian selanjutnya tidak mencantumkan pasal atau bagian tentang syarat. Seharusnya apabila dalam judul tertulis Rukun dan Syarat dan pada bagian rukun ditulis secara eksplisit maka harus ada bagian syarat yang ditulis secara eksplisit, sehingga ada konsistensi.

Dalam hal lain struktur kata antara Rukun dan Syarat, lebih didahulukan kata syarat sehingga redaksinya menjadi "Syarat dan Rukun Perkawinan" karena dalam Ensiklopedi Hukum Islam istilah syarat dan rukun berbeda. Syarat mengandung arti sesuatu yang tergantung padanya keberadaan hukum syar'i (al Hukum asy-syari) dan ia berada di luar hukum itu sendiri, yang ketiadaannya menyebabkan hukum tidak ada, sedangkan rukun adalah sesuatu perbuatan.' Persoalan tentang Rukun dan Syarat yang ada dalam $\mathrm{KHI}$ sama dengan yang ada dalam rancangan UU Hukum Terapan Peradilan Agama, karena secara redaksi dan isi tidak ada perubahan.

\section{Pasal 15}

Pada hakekatnya pasal 15 cukup hanjia satu ayat saja karena dengan istilah sekurang-kurangnya (19 tahun bagi calon suami dan 16 tahun bagi calon isteri) sudah cukup untuk menjadi syarat umur minimal kedua calon. Dengan ditambahkan ayat 2 tentang keharusan adanya izin sebagaimana diatur dalam pasal 6 ayat (2), (3), (4) dan (5) Undang-Undang No. 1 tahun $1974^{8}$ seolah-olah batasan umur yang ada pada pasal 15 ayat 1 belum diperbolehkan.

Berbeda dengan $\mathrm{KHI}$ maka pasal tentang batasan umur yang ada dalam rancangan UU Hukum Terapan Peradilan Agama susunannya menjadi terbalik yang isi lengkapnya sebagai berikut:

Pasal 14 ayat (1): untuk kemaslahatan keluarga dan rumah tangga, perkawinan hanya boleh dilakukan calon mempelai yang telah mencapai umur 21 tahun. Ayat (2): Bagi calon mempelai yang belum mencapai umur 21 tahun harus mendapat izin sebagaimana yang diatur dalam pasal (2), (3), (4) dan (5) UU no. 1 tahun 1974. Ayat (3): Perkawinan hanya diizinkan jika pihak pria sudah mencapai umur 19 tahun dan pihak wanita sudah mencapai umur 15 tahun.Dari ayat tersebut yang agak bias adalah ayat (1) dan (3), karena dalam ayat (1) sudah dibatasi umur kedua calon mempelai 21 tahun, tetapi dalam ayat (3) mengizinkan batasan umur 19 tahun bagi calon suami dan 16 tahun bagi calon isteri.

\section{Pasal 19-23}

Dalam pasal ini dibicarakan tentang masalah wali yang diawali dengan kedudukan wali, yang bertindak sebagai wali dan macam-macam wali.Ternyata dalam pasal ini tidak menyelipkan pasal tentang wali mujbir baik secara eksplisit maupun Implisit. Padahal dalam berbagai kitab fiqh baik klasik maupun moderen membicarakan tentang wali mujbir.

Ada kemungkinan dengan adanya modernisasi persoalan wali mujbir tidak penting untuk dijadikan sebagai acuan dalam mengatur perkawinan, dan dalam kenyataannya untuk menerapkan pelaksanaan perkawinan yang berkaitan dengan wali mujbir adalah sulit. Lebih-lebih lagi pasal 16 ayat (1) yang menyatakan

${ }^{7}$ Abdul Aziz Dahlan, et.al. (editor), 1996, Ensiklopedi Hukum Islam, cet. 1 jilid 5 (Jakarta:PT Ichtiar Baru Van Hoeve) hal. 1510 dan 1691.

${ }^{8}$ Isi lengkap pasal 6 ayat (2), (3), (4) dan (5) lihat Depag Rl 1978/1979 Himpunan Peraturan Perundang-Undangan Badan Peradilan Agama, (Jakarta:Proyek Pembinaan Badan Peradilan Agama Depag RI), hal 6465. 
bahwa perkawinan didasarkan atas persetujuan calon mempelai memberi arti tidak boleh adanya paksaan dalam perkawinan yang berarti pula hak $i j b a r$ tidak berlaku.

\section{Pasal 28}

Persoalan dalam pasal ini adalah masalah redaksi, yang menyebutkan bahwa " Akad nikah dilaksanakan sendiri secara pribadi oleh wali nikah yang bersangkutan." Wali nikah dapat mewakilkan kepada orang lain.

Dua kalimat terpisah dalam persoalan tersebut sebetulnya dapat dijadikan satu menjadi "Akad Nikah dilaksanakan sendiri secara pribadi oleh wali nikah yang bersangkutan, atau dapat mewakilkan kepada orang lain. Pemisahan dua kalimat tersebut memberi kesan berdiri sendiri, padahal masalahnya sama yaitu pelaksanaan akad nikah.

Tidak jauh berbeda isi pasal yang dituangkan dalam Rancangan UU Hukum Terapan Peradilan Agama, dalam masalah akad nikah ini baik isi maupun redaksi yang berarti masalahnya juga sama.

\section{Pasal 34}

Tidak ada perbedaan yang mendasar antara $\mathrm{KHI}$ nomor 1 tahun 1991 dengan Rancangan UU Hukum Terapan Peradilan Agama dalam pasal yang menyangkut mahar. Hanya sedikit perbedaan yang menyangkut redaksi, kalau dalam $\mathrm{KHI}$ pasal 34 ayat (1) menyebut "menyerahkan" adapun dalam rancangan UU Hukum Terapan Peradilan Agama menyebut istilah "membayar".

Sebagai catatan dalam masalah tersebut adalah, apakah status hukum penyerahan dan pembayaran mahar merupakan rukun atau tidak dalam perkawinan.

\section{Studi Evaluasi tentang Dasar Hukum Pemberlakuan Kompilasi Hukum Islam dan Rancangan UU RI tentang Hukum Terapan Peradilan Agama}

Sebelum dikeluarkannya Instruksi Presiden Nomor 1 tahun 1991, ada pihak yang menghendaki agar $\mathrm{KHI}$ ditetapkan dengan putusan Presiden atau dengan Peraturan Pemerintah. Sementara ada juga yang menghendaki agar ditetapkan dengan Undang-undang.

Sebagaimana diketahui, Undangundang, Peraturan Pemerintah, Putusan Presiden berfungsi menetapkan kaidah atau norma hukum atau mencabut/menghapuskannya. Fungsi tersebut berlaku bagi semua norma dengan berbagai adresat (tujuan), baik bersifat kongkret, individual maupun individual konkret.

Sebuah instruksi mempunyai adresatnya bersifat individual. Sebuah instruksi juga memuat hal yang disuruh melakukannya atau dilarang melakukannya, dan tertentu pelaksanaannya atau frekuensinya (satu kali, dua kali, tiga kali, atau beberapa kali), jadi ia bersifat konkret. Artinya norma hukum yang dikandung oleh sebuah instruksi selalu bersifat individual-konkret. Di samping itu, instruksi hanya dapat berlangsung jika antara yang memberi instruksi, dan yang menerima instruksi terdapat hubungan organisasi, lain halnya dengan peraturan.

Sebuah norma hukum yang berisi peraturan, baik dituangkan dalam UndangUndang, Peraturan Pemerintah, Putusan Presiden atau dalam Putusan Menteri, adresat-nya selalu bersifat umum (tidak ditujukan kepada orang-orang tertentu, tetapi 
Topik: Kompilasi Hukum Islam dan Rancangan Undang-Undang RI..., Amir Mu'allim

kepada semua golongan) dan hal yang diaturnya selalu bersifat abstrak (tidak tentu frekuensinya). Dengan demikian, Instruksi Presiden Nomor 1 tahun 1991 tertanggal 10 Juni 1991 berisi norma dengan adresat yang individual (ditujukan kepada Menteri Agama) dan dengan perbuatan yang bersifat kongkret, tertentu, dan berulang kali (menyebarluaskan). ${ }^{9}$

Ide KHI timbul setelah berjalan dua setengah tahun Mahkamah Agung Republik Indonesia membina bidang teknik yustisial Peradilan Agama berdasarkan UndangUndang Nomor 14 tahun 1970. Meskipun undang-undang tersebut ditetapkan pada tahun 1970 , tetapi pelaksanaannya di lingkungan Peradilan Agama baru dapat dilaksanakan pada tahun 1982 setelah ditandatanganinya Surat Keputusan Bersama (SKB) oleh Ketua Mahkamah Agung dan Menteri Agama. SKB itu merupakan jalam pintas tanpa mengganggu lahirnya undang-undang pelaksanaan Undang-Undang Nomor 14 tahun 1970 untuk Peradilan Agama.

- Sebagaimana dimaksudkan dengan "Kompilasi" maka yang ditempuh hanyalah mengumpuikan pendapat-pendapat dalam masalah fiqh yang selama ini dianut oleh umat Islam Indonesia. Jadi bukan "kodifikasi", sebab istilah ini mengandung arti menciptakan hukum baru atau yang telah ada.

Program KHI diharapkan akan menciptakan kepastian hukum di Peradilan Agama, sebab menurut doktrin nasional Indonesia, hukum bisa berlaku dalam arti bisa dipaksakan berlakunya jika ditunjang oleh 3 (tiga) pilar, yaitu aparat hukum, peraturan hukum yang jelas dan kesadaran hukum masyarakat. Aparat hukum telah ada, yaitu Pengadilan Agama. Kesadaran hukum masyarakat adalah tugas para ulama' untuk membinanya. Pilar kedua adalah KHI, sebagai hukum materiil di Peradilan Agama. Merupakan kelanjutan dari instruksi maupun edaran Departemen Agama yang menetapkan 13 kitab sebagai rujukan di Peradilan Agama.

Dengan melihat sejarah, dapat dikatakan bahwa pemikiran tentang Kompilasi Hukum Islam terkandung dalam perkembangan masyarakat itu sendiri. Meskipun telah jelas bahwa pada prinsipnya figh bersumber dari Allah Swt, tetapi dari pengalaman sejarah pula diketahui bahwa pemberlakuannya di negara-negara Islampun selalu atas penetapan pemerintah, terutama dalam masalah pemilihan madzhab yang akan dimuat.

Di lain pihak upaya kompilasi ini akan dapat meyakinkan semua pihak, bahwa jika pemahaman (persepsi) terhadap syari'ah tidak dibenahi kembali, maka kesatuan pendapat dan pandangan kaum muslimin tentang soal-soal kemasyarakatan tidak akan tercapai. KHI dimaksudkan untuk membentuk kesepakatan ulama' Iṇdonesia, tentang segi-segi berlakunya Hukum Islam yang diharapkan akan memperkecil timbulnya beda pendapat.Setelah diadakan lokakarya-lokakarya yang diikuti oleh para pakar hukum Islam dan hukum umum, pada tahap ini diusahakan tercapainya ijma' (konsensus) di antara mereka di dalam suasana bebas dan ilmiah. ${ }^{10}$

Putusan Menteri Agama RI nomor 154 tahun 1991 tertanggal 22 Juli 1991 merupakan tindak lanjut Inpres nomor 1 tahun 1991 yang isi pokoknya adalah:

${ }^{9}$ A. Hamid S. Attamimi, 1996, Dimensi Hukum Islam dalam Sistem Hukum Nasional, (Jakarta: Gema ins'ani Press ), hal. 152-153.

${ }^{10}$ Bustanul Arifin, 1995, Gagasan dan Sasaran KHI, Makalah Seminar KHI, (Suarabaya), hal. 2-8 
a). Seluruh instansi Departemen Agama dan instansi yang lainnya yang terkait agar menyebarluaskan $\mathrm{KHI}$ di bidang Hukum Perkawinan, Kewarisan, dan Perwakafan sebagaimana dimaksud dalam diktum pertama dalam Instruksi Presiden nomor 1 tahun 1991 tertanggal 10 juni 1991 untuk digunakan oleh instansi pemerintah dan masyarakat yang memerlukannya dalam menyelesaikan masalah di bidang tersebut.

b). Seluruh lingkungan instansi tersebut dalam diktum pertama, dalam menyelesaikan masalah-masalah di bidang Hukum Perkawinan, Kewarisan dan Perwakafan sedapat mungkin menerapkan $\mathrm{KHI}$ tersebut di samping peraturan perundangan lainnya.

c). Direktur Jenderal Pembinaan Kelembagaan Agama Islam dan Direktur Jenderal Bimbingan Masyarakat Islam dan Urusan Haji mengkoordinasikan Pelaksanaan Putusan Menteri Agama Republik Indonesia ini dalam bidang tugas masing-masing.

Atas dasar hal tersebut KHI mempunyai daya jangkau ke seluruh masalah yang diaturnya di seluruh wilayah Hukum Islam. Apabila instansi di bawah Departemen Agama, dalam hal ini PA telah menjadikan $\mathrm{KHI}$ sebagai pedoman dalam beracara maupun sebagai sumber hukum, maka secara praktis telah menjadi hukum positif atas dasar konvensi, dalam hal ini ijma' secara diam-diam:

Berdasarkan uraian di atas, khususnya yang bersangkutan dengan norma suatu peraturan yang adresat-nya bersifat umum dan hal yang diatur atau dilakukannya bersifat abstrak, maka terhadap Putusan Menteri Agama RI nomor 154 tahun 1991 tertanggal 22 Juli 1991 perlu diberikan beberapa catatan, yaitu:

a). Suatu putusan mengandung norma yang (1). Umum abstrak, (2). Umum kongkret, (3). Individual kongkret. Norma manakah yang dimaksud oleh Putusan Menteri Agama tersebut? Jelas, tidak mungkin yang dimaksud adalah umum abstrak karena Presiden mengeluarkannya dalam bentuk Instruksi Presiden. Mengapa Menteri Agama melanjutkannya dalam bentuk Putusan yang mengandung berbagai kemungkinan sifat-sifat norma tersebut?

b). Dilihat dari isinya, Putusan Menteri Agama tersebut ternyata sama dengan isi Instruksi Presiden nomor 1 tahun 1991, yaitu mengandung norma hukum yang adresat-nya individual, yaitu jajaran Departemen Agama, sedangkan hal yang disuruh melakukan ialah (1) menyebarluaskan KHI, dan (2) menerapkan KHI. Dilihat dari sifat yang individual-kongkret, ia adalah putusan Instruksi Menteri Agama, bukan Putusan Menteri Agama:

Berkaitan dua catatan tersebut maka agar KHI mempunyai daya ikat atau dalam istilah hukum agar mempunyai daya paksa maka bagi mereka yang menghendaki kekuatan $\mathrm{KHI}$ yang sementara ini masih berbentuk INPRES perlu ditingkatkan menjadi Undang-undang.

Berbeda dengan paham yang menghendaki adanya kepentingan dan kebebasan hakim yang berkaitan dengan peluang untuk mengembangkan pemikiran di bidang Hukum Islam, terutama bagi para hakim agama atau hakim pada umumnya sesuai dengan petunjuk Undang-Undang nomor 7 tahun 1989 yang menyatakan bahwa pengadilan tidak boleh menolak untuk memeriksa dan memutus suatu perkara yang diajukan kepadanya dengan 
dalih bahwa hukum tidak jelas, melainkan wajib memeriksanya. ${ }^{11}$ Hal ini diperkuat pada saat munculnya gagasan adanya Kompilasi Hukum Islam yang pada saat bicara pada landasan yuridis menyatakan bahwa landasan yuridis tentang pentingnya hakim memperhatikan kesadaran hukum masyarakat ialah Undang-undang Nomor 14 tahun 70 pasal 20 (1) yang berbunyi “ Hakim sebagai penegak hukum dan keadilan wajib menggali, mengikuti dan memahami nilainilai hukum yang hidup dalam masyarakat". ${ }^{12}$

Dari berbagai petunjuk di atas, dapat diambil pengertian bahwa kesempatan bagi para hakim untuk secara maksimal menggali potensi-potensi dasar dari berbagai persoalan yang terjadi di masyarakat dan kemudian didialogkan dengan prinsip-prinsip dasar yang ada dalam al-Qur'an dan asSunnah, kemudian diwujudkan dalam bentuk rumusan norma yang dapat djjadikan sebagai standar bagi kehidupan masyarakat, adalah sangat luas. Persoalan baru yang muncul sekarang ini ialah dengan munculnya Inpres nomor 1 tahun 1991 tentang Kompilasi Hukum Islam agaknya membuat terlena bagi para hakim untuk tidak bersusah payah menggali atau menemukan hukum dan cukup membaca apa yang ada dalam Kompilasi Hukum Islam, sehingga nuansa-nuansa pemikiran klasik yang digunakan sebagai modal dalam menghadapi masalah-masalah yang terjadi pada waktu itu kurang mendapat perhatian. Kiranya patut menjadi renungan apa yang dikatakan oleh AA.Feeze bahwa hukum Islam merupakan suatu fenomena yang bertalian erat sekali dengan perkembangan yang terjadi pada masa silam. Hukum Islam yang dikenal dewasa ini adalah sebagai hasil proses perkembangan secara terus menerus selama tersiarnya Islam dalam masa 14 Abad. ${ }^{13}$
Semangat untukmenggali nilai-nilai yang berkembang dalam masyarakat terutama bagi para hakim yang secara formal sebagai ujung tombak dalam menentukan persoalanpersoalan persengketaan yang ada di lembaga peradilan adalah sebagaimana yang diamanatkan oleh Munawir Sadzali yang isinya bahwa beliau minta perhatian berkenaan dengan pasal 209 Kompilasi Hukum Islam (Inpres nomor 1 tahun 1991) yang menggariskan bahwa hakim-hakim agama diwajibkan menggali nilai-nilai hukum yang hidup di dalam masyarakat, agar keputusannya nanti tidak bertentangan dengan semangat keadilan. Artinya hakimhakim itu tetap dituntut untuk berijtihad. Buku Kompilasi Hukum Islam harus dipandang sebagai buku standar untuk hakim-hakim agama di Indonesia dalam menentukan ijthadnya sehingga tidak boleh mematikan perkembangan berfikir para hakim. ${ }^{14}$

Persoalan tersebut mengilhami adanya pendapat yang mempertahankan Kompilasi Hukum Islam tetap posisinya dalam bentuk Inpres dan bukan undang-undang untuk memberikan ruang gerak bagi para hakim dalam menggali, mengikuti dan memahami nilai-nilai hukum yang hidup dalam masyarakat. 1989

11 lihat pasal 56 ayat (1) UU no. 7 tahun

12 Departemen Agama Republik Indonesia, Kompilasi Hukum Islam di Indonesia, 1992-1993 (Jakarta: Direktorat Pembinaan Badan Peradilan Agama Islam Departemen Agama RI), hal. 125

13 AA.Feeze, 1995, Out lines of Muhammad Law (London: Oxford University Press) hlm. 1-2.

${ }^{14}$ Munawir Sadzali, "Peradilan Agama dan Kompilasi Hukum Islam" dalam Mahfud MD.,dkk (editor), 1993, Peradilan Agama dan Kompilasi Hukum Islam dalam Tata Hukum Indonesia (Yogyakarta: UII Press) hal.5 
Topik: Reformasi Peran Hukum Islam di Indonesia

\section{Penutup}

Pemberlakuan Hukum Islam di Indonesia mengalami proses yang panjang dan selalu dalam posisi termarjinalkan. Ini terbukti antara lain pada saat dideklarasikannya UU No. 1 tahun 1974 dan UU No. 7 tahun 1989 yang dalam prosesnya mengalami berbagai tantangan dan hambatan.

Lahirnya Kompilasi Hukum Islam (KHI) sebagai bagian penting dalam kehidupan umat Islam tidak kalah menariknya dalam upaya memperjuangkan terwujudnya $\mathrm{KHI}$ tersebut, sehingga dalam penetapan hukumnya terjadi tolak tarik antara Inpres dan Undang-Undang yang akhirnya lahir dalam bentuk Inpres No. 1 tahun 1991. Keberadaan $\mathrm{KHl}$ yang sekarang ini berbentuk Inpres dan keinginan untuk menaikkan statusnya menjadi Undang-undang memang masingmasing ada plus minusnya dan inilah makna dinamika hukum yang harus menjadi bahan pertimbangan bagi pembuat dan penentu kebijakan terutama yang berkaitan dengan hukum yang diberlakukan di Indonesia.

Perjuangan para cendekiawan, praktisi dan alim ulama dalam merumuskan materi Kompilasi Hukum Islam sangat kita hargai. Begitu pula pemerintah yang sudah merancang Undang-Undang Hukum Terapan Peradilan Agama sebagai kelanjutan dan penyempurnaan $\mathrm{KHI}$, namun demikian dalam beberapa hal terutama yang menyangkut materi ada beberapa catatan yang perlu mendapat perhatian untuk selanjutnya menjadi bahan pertimbangan dalam rangka penyempumaan.

\section{Daftar Pustaka .}

Al Qur'an Al Karim

AA.Feeze, 1995, Out Lines of Muhammad - Law, London: Oxford University Press.
Abdul Aziz Dahlan, et.al. (editor), 1996, Ensiklopedi Hukum Islam, cet. 1 jilid 5, Jakarta: PT. Ichtiar Baru Van Hoeve

Hamid S. Attamimi, 1993, Dimensi Hukum Islam dalam Sistem Hukum Nasional, Jakarta: Gema Insani Press.

Bustanul Arifin, 1995, Gagasan dan Sasaran $K H I$, Makalah Seminar KHI, di Surabaya

Departemen Agama Republik Indonesia, Kompilasi Hukum Islam di Indonesia, Jakarta: Direktorat Pembinaan Badan Peradilan Agama Islam.

Depag RI 1978/1979 Himpunan Peraturan Perundang-Undangan Badan Peradilan Agama, Jakarta: Proyek Pembinaan Badan Peradilan Agama.

Jalaludin As Suyuthi, t.th, Al Asybah wan Nadzair fil Furu (Beirut:Darul Fikri)

Munawir Sadzali, "Peradilan Agama dan Kompilasi Hukum Islam" dalam Mahfud MD.,dkk (editor), 1993, Peradilan Agama dan Kompilasi Hukum Islam dalam Tata Hukum Indonesia (Yogyakarta: Uil Press)

Mahfud MD dkk (Editor), 1993, Peradilan Agama \& Kompilasi Hukum Islam dalam Tata Hukum Indonesia, Yogyakarta: UII Press

Roihan A Rasyid, 1991, Hukum Acara Peradilan Agama, cet.2, Jakarta: Rajawali Press

Sudirman Tebba, 2003, Sosiologi Hukum Islam, cet.1, (Yogyakarta: UII Press) 